\title{
Prinsip Maksimum Pontryagin Dalam Masalah Kontrol Optimum Stokastik
}

\author{
Effendi Syahril \\ Departemen Matematika, \\ Fakultas Matematika dan Imu Pengetahuan Alam, \\ Institut Pertanian Bogor \\ Jl. Meranti, Kampus IPB Darmaga, Bogor, 16680 Indonesia
}

\begin{abstract}
ABSTRAK
Kontrol Optimum Stokastik merupakan cabang matematika yang relatif baru perkembangannya. Terdapat dua pendekatan untuk menentukan solusi masalah kontrol optimum stokastik, yaitu prinsip maksimum Pontryagin dan program dinamis Bellman. Tulisan ini menyajikan prinsip maksimum untuk masalah kontrol optimum stokastik dan aplikasinya dalam masalah portofolio dan konsumsi. Merton(1971) menyelesaikan masalah konsumsi dan portofolio dengan menggunakan pendekatan program dinamis. Dengan hasil yang diperoleh oleh Merton sebagai patokan, masalah konsumsi dan portofolio diselesaikan dengan pendekatan prinsip maksimum.

Kata Kunci. Prinsip Maksimum Stokastik, peubah adjoint, masalah konsumsi dan portofolio.
\end{abstract}

\section{Pendahuluan}

Teori kontrol optimum stokastik merupakan cabang ilmu matematika yang masih relatif baru apabila dibandingkan dengan teori kontrol optimum deterministik. Studi tentang kontrol optimum stokastik ini baru berjalan dalam beberapa dekade terakhir. Namun demikian, penggunaan kontrol optimum stokastik sangat menarik. Aplikasi kontrol optimum stokastik sangat luas, antara lain pada bidang-bidang teknik/rekayasa, pengendalian satelit, keuangan, ekonomi, masalah produksi dan 
inventori, dan masalah konsumsi sumber daya alam, seperti yang dapat dilihat dalam Benes, Shepp dan Witsenhausen (1980), Bensoussan, Hurst dan Naslund (1974), Bensoussan, Kleindorfer dan Tapiero (1980), Merton (1971), Sethi dan Thompson (1981). Pada umumnya, aplikasi kontrol optimum tersebut menggunakan pendekatan program dinamis. Sedangkan penggunaan prinsip maksimum dapat dilihat pada Haussmann (1981).

Masalah kontrol optimum stokastik yang menjadi perhatian dalam tulisan ini adalah dalam bentuk berikut ini : Ingin diminimumkan fungsi ongkos/biaya

$$
J(u(t))=E\left(\int_{0}^{T} f(x(t), u(t), t) d t+S(x(T))\right.
$$

dengan kendala dalam bentuk persamaan diferensial stokastik atau persamaan diferensial Itô

$$
\begin{aligned}
d x(t) & =\alpha(x(t), u(t), t) d t+\sigma(x(t), u(t), t) d B(t) \\
x(o) & =x_{0}
\end{aligned}
$$

dengan $u(t)$ adalah fungsi peubah kontrol yang nilainya terdapat dalam himpunan bagian tertutup $R^{m}$, peubah $x(t)$ merupakan trajektori, $B(t)$ adalah gerak Brown standar, $E$ melambangkan nilai harapan, serta $f, S, \alpha$ dan $\sigma$ adalah fungsi-fungsi yang diberikan. Dalam persamaan diferensial Itô, fungsi $\alpha$ dan fungsi $\sigma$ berturutturut disebut sebagai koefisien drift dan koefisien difusi.

Tulisan ini memiliki 2 tujuan. Tujuan pertama adalah untuk menyajikan prinsip maksimum yang memiliki peranan penting dalam kontrol optimum- stokastik. Prinsip maksimum dalam masalah kontrol optimum stokastik telah ditelaah, seperti yang dilaporkan dalam beberapa makalah, misalnya dalam Kushner (1972), Haussmann (1981), (1986), Bensoussan (1982a) dan Bensoussan, et. al. (1974). Namun demikian, dalam tulisan tersebut, peubah kontrol hanya terdapat dalam koefisien drift. Sehingga, teknik prinsip maksimum ini tidak dapat digunakan untuk, misalnya masalah konsumsi dan portofolio, seperti yang dikembangkan oleh Merton (1971). Untungnya, dalam tulisan mereka yang sangat menarik, Bensoussan (1982b), Elliott (1990) dan Peng (1990) merumuskan prinsip maksimum untuk masalah kontrol optimum stokastik apabila kontrol juga terdapat dalam koefisien difusi. Bensoussan (1982b) memfokuskan pembahasan pada masalah kontrol optimum stokastik untuk masalah dengan himpunan kontrol admissible merupakan himpunan konveks. Akan tetapi, perhitungan Bensoussan ini terlalu rumit karena melibatkan integran stokastik yang tidak diketahui. Elliott (1990) membuat perhitungan menjadi lebih sederhana dengan menggunakan hasil-hasil pada sifat diferensiabel solusi persamaan diferensial stokastik yang bergantung pada parameter. Sementara Peng (1990) membahas masalah kontrol optimum stokastik untuk himpunan kontrol admissible yang tidak harus dalam bentuk konveks. 
Tujuan kedua tulisan ini adalah menyajikan aplikasi prinsip maksimum pada masalah khusus, yaitu masalah konsumsi dan portofolio. Merton (1971) merupakan orang pertama yang menentukan solusi dari masalah ini. Teknik kontrol optimum yang digunakan oleh Merton adalah pendekatan program dinamis. Dengan menurunkan persyaratan keoptimalan, Merton berhasil menentukan solusi masalah konsumsi dan portofolio tersebut secara eksplisit. Dengan menggunakan solusi yang diperoleh Merton sebagai patokan, akan ditentukan solusi masalah konsumsi dan portofolio dengan menggunakan prinsip maksimum.

Sistematika penulisan selanjutnya adalah sebagai berikut. Dalam bagian kedua disajikan prinsip maksimum stokastik. Pada bagian ketiga disajikan masalah konsumsi dan portofolio serta solusinya seperti yang dikembangkan oleh Merton. Selanjutnya dalam bagian keempat digunakan prinsip maksimum untuk menyelesaikan masalah konsumsi dan portofolio Merton. Pada bagian terakhir, diberikan kesimpulan dan diskusi tentang hasil-hasil pada prinsip maksimum.

\section{Prinsip Maksimum Stokastik}

Masalah kontrol optimum stokastik yang akan menjadi pokok bahasan adalah dalam bentuk berikut ini :

Minimumkan fungsi biaya

$$
J[u(t)]=E\left\{\int_{0}^{T} f[x(t), u(t), t] d t+S[x(T)]\right\}
$$

dengan kendala dalam bentuk persamaan diferensial stokastik

$$
\begin{aligned}
d x(t) & =\alpha(x(t), u(t), t) d t+\sigma(x(t), u(t), t) d B(t) \\
x(0) & =x_{0}
\end{aligned}
$$

\footnotetext{
Dalam masalah kontrol optimum stokastik di atas, $u(t)$ merupakan peubah kontrol yang nilainya terdapat dalam himpunan bagian dari $R^{m}$, yang bersifat tertutup dan konveks, sedangkan $x(t)$ merupakan trajektori atau peubah keadaan (state) dari sistem, $B(t)$ adalah gerak Brown dalam bentuk standar, operator $E$ merepresentasikan nilai harapan matematika, dan $f, S, \alpha$, dan $\sigma$ merupakan fungsi-fungsi yang diberikan. Dalam bagian ini akan disajikan syarat perlu untuk adanya kontrol optimum, yang dikenal dengan prinsip maksimum. Juga dibicarakan ketersediaan syarat cukup untuk kontrol supaya menjadi kontrol optimum. Terdapat banyak kajian yang berkaitan dengan penurunan syarat perlu untuk adanya kontrol optimum. Beberapa diantaranya adalah kajian dari Kushner (1972), Bensoussan (1982), Bensoussan, et.al (1974), Haussmann (1986), Elliott (1990) dan Peng (1990). Untuk masalah kontrol optimum stokastik dengan koefisien
} 
difusi konstanta, Bensoussan, et.al (1974) menurunkan prinsip maksimum menggunakan pendekatan program dinamis. Penurunan ini, menghasilkan himpunan kontrol yang admissible berupa himpunan konveks, yang berujung pada syarat cukup untuk kontrol optimum. Sementara itu, untuk masalah kontrol optimum stokastik dengan koefisien difusi hanya bergantung pada waktu $t$ dan peubah state $x(t)$, penurunan syarat perlu dapat ditemukan dalam Kushner (1972), Haussmann (1986) dan juga dalam Bensoussann (1982). Kajian Haussmann (1986) menunjukkan bahwa dengan persyaratan tertentu, seperti himpunan kontrol yang admissible berupa himpunan konveks, prinsip maksimum juga merupakan syarat cukup untuk kontrol optimum.

Untuk masalah kontrol optimum stokastik dengan bagian difusi dibolehkan bergantung pada peubah kontrol, penurunan prinsip maksimum diinvestigasi oleh Bensoussann (1982), Elliott (1990) dan Peng (1990). Bensoussann dan Elliott memfokuskan pembahasan mereka pada masalah kontrol optimum stokastik dengan himpunan kontrol admissible berupa himpunan konveks. Pada kenyataannya, Elliott membuat penyederhanaan perhitungan Bensoussann. Sementara itu Peng (1990) membahas prinsip maksimum untuk masalah kontrol optimum stokastik yang lebih umum, yaitu untuk masalah kontrol dengan himpunan kontrol yang admissibel tidak harus berupa himpunan konveks.

Dari pembahasan di atas dapat disimpulkan bahwa banyak cara untuk menurunkan prinsip maksimum, misalnya melalui prinsip keoptimalan Bellman. Penurunan dalam tulisan ini mengikuti pendekatan yang digunakan oleh Bensoussann. Alasan utama adalah karena kajian Bensoussann merupakan referensi yang sudah baku. Selain itu, penyajian Bensoussann relatif mudah diikuti, dan yang lebih penting lagi, metode Bensoussann memenuhi kriteria aplikasi masalah yang akan dibahas dalam tulisan ini.

\subsection{Perumusan Masalah}

Misalkan $(\Omega, F, P)$ merupakan ruang peluang yang dilengkapi dengan filtrasi $F^{t}$. Misalkan $B(t)$ merupakan gerak Brown standar yang nilainya terdapat di $R^{n}$. Kita asumsikan bahwa

$$
F^{t}=\{B(t): 0 \leq s \leq t\}
$$

adalah $\sigma$-aljabar yang dibangun oleh $B(t)$.

Perhatikan sistem kontrol stokastik

$$
\begin{aligned}
d x(t) & =\alpha(x(t), u(t), t) d t+\sigma(x(t), u(t), t) d B(t) \\
x(0) & =x_{0}
\end{aligned}
$$

dan asumsikan fungsi $\alpha$ dan $\sigma$ keduanya fungsi kontinu dan terturunkan terhadap $x$ dan $u$, dan juga asumsikan $\alpha_{x}, \alpha_{u}, \sigma_{x}, \sigma_{u}$ merupakan fungsi-fungsi berbatas. 
Misalkan $L_{F}^{2}(0, t)=\left\{u(t) \in L^{2}\left(\Omega, F^{t}, P ; R^{m}\right)\right\}$ merupakan ruang bagian Hilbert dari $L^{2}$. Misalkan $U_{a d}$ berupa himpunan bagian dari $R^{m}$, dan $U_{a d}$ adalah himpunan tak hampa, tertutup, dan konveks. Definisikan himpunan semua kontrol yang admissible

$$
U=\left\{u \in L_{F}^{2}(0, T): u(t) \in U_{a d}, \text { a.e., a.s. }\right\}
$$

Catatan : a.e. merupakan singkatan untuk almost every where, sedangkan a.s. merupakan singkatan untuk almost surely.

Remark 2.1 Himpunan kontrol admissible $U$ adalah himpunan konveks dan tertutup dan $U \subset L_{F}^{2}(0, T)$.

Remark 2.2 Karena asumsi bahwa $\alpha(x, u, t)$ dan $\sigma(x, u, t)$ kontinu dan terturunkan serta turunannya terhadap $x$ dan u berbatas, maka untuk sebarang kontrol admissible $u \in U$, persamaan diferensial stokastik sistem kontrol persamaan (6) dapat ditentukan solusinya.

Misalkan diasumsikan $f(x, u, t)$ berupa fungsi kontinu dan terturunkan serta turunannya terhadap $x$ dan $u$ berbatas. Juga diasumsikan bahwa fungsi $S$ merupakan fungsi kontinu dan terturunkan serta turunan terhadap $x$ berbatas. Masalah kontrol optimum stokastik dapat dituliskan menjadi masalah meminimumkan fungsional biaya diantara kontrol admissible $U$

$$
J[u(t)]=E\left\{\int_{0}^{T} f(x(t), u(t), t) d t+S(x(T))\right\}
$$

terhadap kendala

$$
\begin{aligned}
d x(t) & =\alpha(x(t), u(t), t) d t+\sigma(x(t), u(t), t) d B(t) \\
x(0) & =x_{0}
\end{aligned}
$$

Remark 2.3 Walaupun masalahnya berupa meminimumkan biaya, teknik dalam literatur tetap disebut prinsip maksimum.

Notasi : Notasi berikut akan digunakan dalam pembahasan selanjutnya :

1. Operator '*' menyatakan transpos

2. Operator $<., .>$ menyatakan hasil kali dalam atau inner product 
maka diperoleh

dengan

$$
\begin{aligned}
-d p & =\left[\left(\alpha_{x}^{*} p+f_{x}\right)-<\sigma_{x}^{*}, K>\right]+K d B(t) \\
p(T) & =S_{x}(x(T))
\end{aligned}
$$

dengan $K$ didefinisikan oleh

$$
K(t)=\sigma_{x}^{*}(t) p(t)-\Psi^{*}(t) G(t)
$$

dan matriks $\Psi$ memenuhi persamaan diferensial

$$
\begin{aligned}
d \Psi & =-<\Psi \sigma_{x}, d B>+\left[<\Psi \sigma_{x}, \sigma_{x}>-\Psi \alpha_{x}\right] d t \\
\Psi(0) & =I,
\end{aligned}
$$

dengan I merupakan matriks identitas, sedangkan $G$ memenuhi persamaan integral

$$
E^{F^{t}}\{A\}=E\{A\}+\int_{0}^{t} G(s) d B(s),
$$

$$
A=Q^{*}(T) S_{x}(x(T))+\int_{0}^{T} Q^{*}(s) f_{x}(x(s), u(s), s) d s
$$

dan matriks $Q$ memenuhi

$$
\begin{aligned}
d Q & =\alpha_{x} Q d t+<\sigma_{x} Q, d B> \\
Q(0) & =I .
\end{aligned}
$$

Definisikan fungsi Hamilton dengan

$$
H(x, u, t ; p, K)=p . \alpha(x, u, t)+f(x, u, t)-\operatorname{tr} K \sigma^{*}(x, u, t)
$$

$$
\frac{\partial H}{\partial v}(x(t), u(t), t ; p(t), K(t)) .(v-u(t)) \geq 0 \text {, a.e.t, a.s., } \forall v \in U .
$$


Bukti : Bukti teorema ini dapat dilihat dalam Syahril (1991).

Remark 2.5 Persamaan adjoint (10) bergantung pada peubah stokastik yang tidak diketahui $G$ yang didefinisikan oleh persamaan (13). Persamaan integrasi (13) ditemukan oleh Kunita-Watanabe, seperti yang dilaporkan oleh Peng(1990). Sangat sulit untuk menentukan solusi persamaan adjoint (10).

Untuk menghindari kesulitan tersebut, Elliott (1990) menemukan representasi yang sangat elegan untuk peubah adjoint $p$. Menurut Elliott(1990), peubah adjoint haruslah memenuhi persamaan

$$
\begin{aligned}
p_{t}(t) & +p_{x}(t) g(t)+l_{x}(t)+p(t) g_{x}(t) \\
& +\frac{1}{2} \sum_{i=1}^{n} p_{x x}(t) \sigma^{(i)}(t) \times \sigma^{(i)}(t)=0, \\
p(T) & =h_{x}(x(T)) .
\end{aligned}
$$

Fungsi Hamilton yang bersesuaian diberikan oleh

$$
H(x, v, t, p)=p g(x, v, t)+l(x, v, t)+\sum_{i=1}^{n} p_{x}(t) \sigma^{(i)}(x, u, t) \sigma^{(i)}(x, v, t),
$$

dan prinsip maksimum diberikan oleh

$$
\frac{\partial H}{\partial v}(x(t), u(t), t, p \cdot(v-u(t)) \geq 0
$$

a.e. $t$, hampir pasti untuk semua $v \in U$.

\section{Masalah Portofolio dan Konsumsi}

Dalam model pemilihan portofolio dan konsumsi, Merton (1971) merumuskan persamaan kekayaan dalam bentuk persamaan diferensial stokastik. Persamaan ini dikenal dengan nama persamaan budget. Merton (1971) mengasumsikan harga aset memiliki distribusi log normal, sehingga cukup dilihat hanya 2 aset saja, yaitu aset bebas resiko dan aset beresiko. Harga setiap aset bebas resiko, dilambangkan oleh $P_{1}(t)$, berkembang mengikuti persamaan diferensial biasa

$$
d P_{1}(t)=r P_{1}(t) d t
$$

dengan $r$ menyatakan rate of return atau tingkat imbal hasil, sedangkan harga aset beresiko, dilambangkan oleh $P_{2}(t)$, berkembang mengikuti persamaan diferensial stokastik

$$
d P_{2}(t)=\alpha P_{2}(t) d t+\sigma P_{2}(t) d B(t)
$$


dengan $\alpha$ melambangkan rata-rata perubahan harga per satuan waktu, dan $\sigma$ melambangkan variansi dari perubahan harga per satuan waktu. Parameter $r, \alpha, \sigma$ adalah konstanta dan $\{B(t): t \geq 0\}$ merepresentasikan gerak Brown bernilai real.

Misalkan $W(t), \quad t \geq 0$ menyatakan kekayaan pada waktu $t$ dari pemodal yang menginvestasikan kekayaannya pada kedua tipe aset di atas. Misalkan $u_{1}(t)$ menyatakan proporsi kekayaan yang diinvestasikan pada aset beresiko pada waktu $t$, dan $u_{2}(t)$ menyatakan tingkat konsumsi pada waktu $t$. Maka persamaan budjet atau kekayaan pemodal tersebut adalah

$$
\begin{aligned}
d W(t)= & {\left[1-u_{1}(t)\right] W(t) r d t+u_{1}(t) W(t)[\alpha d t+\sigma d B(t)] } \\
& -u_{2}(t) d t \\
W(0)= & W_{0}
\end{aligned}
$$

dengan $W_{0}>0$ menyatakan jumlah kekayaan awal. Kontrol yang digunakan dalam masalah ini adalah kontrol 2-dimensi, $u(t)=\left(u_{1}(t), u_{2}(t)\right)$, dengan batasan $0 \leq u_{1}(t) \leq 1$, dan $u_{2}(t) \geq 0$.

Masalah pemilihan portofolio dan konsumsi optimum bagi pemodal yang hidup sampai tahun ke- $T$ dirumuskan sebagai berikut

$$
J[u(t), t]=\max E\left\{\int_{0}^{T} U\left[u_{2}(t), t\right] d t+S[W(T), T]\right\}
$$

dengan kendala persamaan (23), dan fungsi utilitas $U$ diasumsikan berupa fungsi konkaf (cembung) dalam $u_{2}$, dan fungsi warisan $S$ diasumsikan bersifat konkaf dalam $W$.

Misal diasumsikan fungsi utilitas untuk pemodal $U\left[u_{2}(t), t\right]$ dapat dituliskan dalam bentuk

$$
U\left[u_{2}(t), t\right]=\exp (-\rho t) V\left[u_{2}(t)\right]
$$

dengan $\rho>0$ merupakan tingkat diskonto, fungsi $V$ merupakan anggota fungsifungsi utilitas yang memiliki risk-aversion bersifat positif dan hiperbola dalam konsumsi. Fungsi $V$ ini dapat dituliskan dalam bentuk

$$
V\left[u_{2}(t)\right]=\frac{1-q}{q}\left[\frac{b u_{2}(t)}{1-q}+n\right]^{q},
$$

dengan batasan $q \neq 1, \quad b>0, \quad \frac{b u_{2}(t)}{1-q}+n>0, \quad n=1$ jika $q=-\infty$. Sehingga, dengan asumsi fungsi warisan $S=0$, masalah pemilihan portofolio dan konsumsi optimum menjadi

$$
J[u(t), t]=\max E\left\{\int_{0}^{T} \exp (-\rho t) V\left[u_{2}(t)\right] d t\right\}
$$


dengan kendala persamaan (23).

Menggunakan metode program dinamis stokastik, Merton (1971) menurunkan persyaratan keoptimalan

$$
\begin{aligned}
J_{t} & +\left[\frac{(1-q) n}{b}+r W\right] J_{W}-\frac{(\alpha-r)^{2}}{2 \sigma^{2}} \frac{J_{W}^{2}}{J_{W W}} \\
& +\frac{(1-q)^{2}}{q} \exp (-\rho t)\left[\frac{\exp (\rho t) J_{W}}{b}\right]^{\frac{q}{1-q}}=0
\end{aligned}
$$

dengan persyaratan $J(W, T)=0$, dan fungsi $J(W, t)$ merupakan fungsi deterministik. Suatu solusi dari persamaan diferensial parsial ordo dua (27) adalah

$$
\begin{aligned}
J(W, t) & =\frac{s b^{q}}{q} \exp (-\rho t)\left[\frac{s\left[1-\exp \left(\frac{-(\rho-q v)(T-t)}{s}\right)\right]}{-q v}\right]^{s} \\
& \times\left[\frac{W}{s}+\frac{n}{b r}[1-\exp (-r(T-t))]\right]^{q}
\end{aligned}
$$

dengan $s=1-q$, dan $v=r+\frac{(\alpha-r)^{2}}{2 s \sigma^{2}}$.

Persamaan untuk portofolio dan konsumsi optimum adalah

$$
\begin{aligned}
& u_{2}(t)=\frac{1-q}{b}\left(\frac{\exp (\rho t) J_{W}}{b}\right)^{\frac{1}{q-1}}-\frac{(1-q) n}{b} \\
& u_{1}(t)=-\frac{(\alpha-r)}{\sigma^{2}} \frac{J_{W}}{J_{W W} W} .
\end{aligned}
$$

Dari persamaan ( 28), ( 29) dan ( 30$)$, portofolio dan konsumsi optimum dapat dituliskan dalam bentuk eksplisit

$$
\begin{aligned}
& u_{2}(t)=\frac{(\rho-q v)\left(W(t)+\frac{s n}{b r}(1-\exp ([r(t-T)])\right.}{s\left(1-\exp \left(\frac{(\rho-q v)(t-T)}{s}\right)\right)}-\frac{s n}{b} \\
& u_{1}(t)=\frac{\alpha-r}{s \sigma^{2}}+\frac{n(\alpha-r)}{b r \sigma^{2} W(t)}(1-\exp (r(t-T))) .
\end{aligned}
$$

Remark 3.1 Karakteristik utama dalam persamaan (31) adalah fungsi konsumsi merupakan fungsi linier dari fungsi kekayaan, dan dalam persamaan (32) adalah fungsi investasi berbanding terbalik dengan fungsi kekayaan.

Remark 3.2 Fleming and Rishel (1975) menyelesaikan masalah portofolio dan konsumsi untuk fungsi utilitas $U\left[u_{2}(t), t\right]=u_{2}^{s}, \quad 0<s<1$. Solusi optimum yang diperoleh adalah $u_{1}^{\star}(t)$ merupakan konstanta dan $u_{2}^{\star}(t)$ merupakan fungsi linier dalam kekayaan $W(t)$. 


\section{Aplikasi Prinsip Maksimum Stokastik Pada Model Merton}

Untuk aplikasi prinsip maksimum pada masalah Merton, dituliskan kembali masalahnya dalam bentuk berikut ini :

$$
J[u(.)]=E\left\{\int_{0}^{T}-\frac{1-q}{q} \exp (-\rho t)\left[\frac{b u_{2}(t)}{1-q}+n\right]^{q} d t\right\}
$$

dengan kendala persamaan kekayaan

$$
\begin{aligned}
d W(t)= & {\left[r W(t)+(\alpha-r) W(t) u_{1}(t)-u_{2}(t)\right] d t } \\
& +\sigma W(t) u_{1}(t) d B(t) \\
W(0)= & W_{0}
\end{aligned}
$$

Misalkan $u^{\star}(t)=\left(u_{1}^{\star}(t), u_{2}^{\star}(t)\right)$ sebagai kontrol optimum, dan $\hat{W}(t)$ merupakan trajektori optimum yang berkaitan yang didefinisikan oleh

$$
\begin{aligned}
d \hat{W}(t)= & {\left[r \hat{W}(t)+(\alpha-r) \hat{W}(t) u_{1}^{\star}(t)-u_{2}^{\star}(t)\right] d t } \\
& +\sigma \hat{W}(t) u_{1}^{\star}(t) d B(t) \\
\hat{W}(0)= & W_{0} .
\end{aligned}
$$

Peubah adjoint $p(t)$ merupakan solusi dari

$$
\begin{aligned}
-d p(t) & =\left[\left(r+(\alpha-r) u_{1}^{\star}(t) p(t)-<\sigma u_{1}^{\star}(t), K>\right] d t+K d B(t)\right. \\
p(T) & =0 .
\end{aligned}
$$

Menggunakan persamaan (16), diperoleh fungsi Hamilton

$$
\begin{aligned}
H\left(\hat{W}, u^{\star}, t ; p, K\right) & =\left[\left(r+(\alpha-r) u_{1}\right) \hat{W}-u^{\star}\right] p \\
& -\frac{(1-q)}{q} \exp (-\rho t)\left(\frac{b u_{2}^{\star}}{1-q}+n\right)^{q}-\operatorname{tr} K \sigma \hat{W} u_{1}^{\star} .
\end{aligned}
$$

Dengan mengaplikasikan prinsip maksimum persamaan (17) pada fungsi Hamilton persamaan (38), dan dengan membuat turunan $H$ terhadap $u_{1}$ sama dengan nol, menghasilkan

$$
K=\frac{(\alpha-r)}{\sigma} p
$$

Turunan fungsi $H$ terhadap $u_{2}$ sama dengan nol memberikan

$$
p+b \exp (-\rho t)\left(\frac{b u_{2}^{\star}}{1-q}+n\right)^{q-1}=0 .
$$


Fleming dan Rishel (1975) dan Haussmann (1986) menunjukkan bahwa ada kontrol optimum dalam bentuk umpan balik. Berdasarkan ini, ingin dicari fungsi adjoint $p(t)$ demikian rupa sehingga dipenuhi

$$
p(t)=-\frac{\partial L}{\partial W}
$$

dengan $L(W, t)$ melambangkan fungsi deterministik yang tidak diketahui. Dengan menggunakan formula Itô pada persamaan (41) akan diperoleh

$$
d p=-\left[\frac{\partial^{2} L}{\partial t \partial W}+\frac{\partial^{2} L}{\partial W^{2}} d \hat{W}+\frac{1}{2} \frac{\partial^{3} L}{\partial W^{3}} d \hat{W}^{2}\right]
$$

Dengan memanfaatkan $d \hat{W}$ seperti dalam persamaan (35), dan diaplikasikan pada persamaan 42, menghasilkan

$$
\begin{aligned}
d p & =-\left[\frac{\partial^{2} L}{\partial t \partial W}+\left(r \hat{W}+(\alpha-r) \hat{W} u_{1} \star-u_{2}^{\star}\right) \frac{\partial^{2} L}{\partial W^{2}}\right. \\
& \left.+\frac{1}{2} \hat{W}^{2} u_{1}^{\star} \frac{\partial^{3} L}{\partial W^{3}}\right] d t-\sigma \hat{W} u_{1}^{\star} \frac{\partial^{2} L}{\partial W^{2}} d B(t) .
\end{aligned}
$$

Langkah selanjutnya, dengan mensubstitusi $K$ yang didefinisikan dalam persamaan (39) kedalam persamaan (37), sehingga diperoleh

$$
\begin{aligned}
-d p & =r p d t+\frac{\alpha-r}{\sigma} p d B(t) \\
p(T) & =0 .
\end{aligned}
$$

Dengan identifikasi persamaan (43) dan persamaan (44), koefisien $d B(t)$ memberikan

$$
\hat{W} u_{1}^{\star} \frac{\partial^{2} L}{\partial W^{2}}=\frac{\alpha-r}{\sigma} p .
$$

Karena menurut persamaan $(41) p(t)=-\frac{\partial L}{\partial W}$, maka didapat

$$
u_{1}^{\star}=-\frac{\partial L / \partial W}{\partial^{2} L / \partial W^{2}} \frac{1}{W} \frac{(\alpha-r)}{\sigma^{2}} .
$$

Dari persamaan (40) dan persamaan (41) diperoleh

$$
u_{2}^{\star}=-\frac{1-q}{b} n+\frac{1-q}{b}\left[\frac{\exp (\rho t)}{b} \frac{\partial L}{\partial W}\right]^{\frac{1}{q-1}} .
$$

Dengan cara yang sama, identifikasi persamaan (43) dan persamaan (44), koefisien $d t$ menghasilkan

$$
-r \frac{\partial L}{\partial W}=\frac{\partial^{2} L}{\partial t \partial W}+\left[r \hat{W}+(\alpha-r) \hat{W} u_{1}^{\star}-u_{2}^{\star}\right] \frac{\partial^{2} L}{\partial W^{2}}+\frac{1}{2} \sigma^{2} \hat{W}^{2} u_{1}^{\star 2} \frac{\partial^{3} L}{\partial W^{3}} .
$$


Dengan memanfaatkan nilai $u_{1}^{\star}$ dan nilai $u_{2}^{\star}$, dan tanpa kehilangan sifat keumuman, maka dapat ditunjukkan bahwa

$$
\begin{aligned}
L_{t} & +\left[r \hat{W}+\frac{(1-q)}{b} n\right] L_{W}-\frac{(\alpha-r)^{2}}{2 \sigma^{2}} \frac{L_{W}^{2}}{L_{W W}}-\frac{(1-q)}{b} \\
& +\left[\frac{\exp (\rho t)}{b} L_{W}\right]^{\frac{1}{(q-1)}} L_{W} \frac{1-q}{q} \exp (-\rho t)\left[\frac{\exp (\rho t)}{b} L_{W}\right]^{\frac{q}{q-1}}=0 .
\end{aligned}
$$

Persamaan ini tidak lain adalah persyaratan keoptimalan seperti persamaan (27) yang diturunkan dengan prinsip program dinamis stokastik. Dengan menggunakan solusi yang diberikan dalam persamaan (28) untuk persamaan (49), maka dapat ditemukan solusi untuk masalah portofolio dan konsumsi. Solusinya diberikan oleh persamaan (31) dan persamaan (32).

Remark 4.1 Untuk masalah khusus ini, prinsip maksimum tidak memberikan bentuk tertutup untuk kontrol $u_{1}^{\star}$, karena fungsi Hamilton merupakan fungsi linier dalam $u_{1}^{\star}$. Sebaliknya, karena fungsi Hamilton bukan fungsi linier dalam $u_{2}^{\star}$, maka prinsip maksimum menghasilkan fungsi kontrol optimum $u_{2}^{\star}$ dalam bentuk tertutup.

Remark 4.2 Untuk memperoleh $u_{1}^{\star}$ digunakan teknik lain. Teknik ini berdasarkan pada kenyataan bahwa kontrol optimum dapat dituliskan dalam bentuk tertutup, seperti yang dinyatakan oleh Fleming and Rishel (1975). Teknik yang digunakan diawali dengan asumsi bahwa fungsi adjoint merupakan fungsi turunan dari fungsi deterministik yang belum diketahui. Teknik ini berujung pada penentuan kriteria keoptimalan seperti yang dihasilkan oleh teknik program dinamis stokastik.

Dengan mengaplikasikan hasil yang diperoleh Elliott (1990), yaitu persamaan (18) dan persamaan (19) terhadap masalah portofolio dan konsumsi sebagaimana yang dikembangkan oleh Merton, maka diperoleh proses adjoint $p$ yang memenuhi

$$
\begin{aligned}
p_{t} & +\left[r+(\alpha-r) u_{1}^{\star}\right] p+\left[r \hat{W}+(\alpha-r) \hat{W} u_{1}^{\star}-u_{2}^{\star}\right] p_{W} \\
& +\frac{1}{2} \sigma^{2} \hat{W}^{2} u_{1}^{\star 2} p_{W W}=0, \\
p(T) & =0 .
\end{aligned}
$$

Fungsi Hamilton diberikan dalam bentuk

$$
\begin{aligned}
H(W, u, t, p) & =-\frac{1-q}{q} \exp (-\rho t)\left[\frac{b u_{2}(t)}{1-q}+n\right]^{q}+[r \hat{W} \\
& \left.+(\alpha-r) \hat{W} u_{1}-u_{2}\right] p+\sigma^{2} \hat{W}^{2} u_{1}^{2} p_{W}
\end{aligned}
$$


Pada gilirannya, fungsi Hamilton memberikan kontrol optimum

$$
\begin{aligned}
u_{1}^{\star}(t) & =-\frac{(\alpha-r) p(t)}{2 \sigma^{2} \hat{W} p_{W}} \\
u_{2}^{\star}(t) & =-\frac{1-q}{b} n+\frac{1-q}{b}[-\exp (\rho t) p(t)]^{\frac{1}{q-1}} .
\end{aligned}
$$

\section{Kesimpulan dan Diskusi}

Telah disajikan syarat perlu, yang disebut dengan prinsip maksimum, untuk masalah kontrol optimum stokastik dengan fungsi kontrol terdapat dalam koefisien drift maupun koefisien difusi. Masalah kontrol optimum stokastik yang dibahas merupakan masalah kontrol optimum dengan kontrol admissible berupa himpunan konveks. Kunci utama dalam prinsip maksimum dalam masalah kontrol optimum stokastik adalah peubah adjoint. Penyajian peubah adjoint dalam tulisan ini, dan juga penyajian prinsip maksimum, mengikuti penyajian yang diberikan oleh Bensoussan (1982). Penyajian Bensoussan mengenai peubah adjoint, demikian rupa sehingga peubah adjoint memenuhi persamaan diferensial Itô. Akan tetapi, penyajian Bensoussan ini memunculkan kesulitan dalam penghitungan, karena persamaan diferensial yang dipenuhi melibatkan penghitungan fungsi integran stokastik yang tidak diketahui. Nyatanya, kesulitan penghitungan yang muncul karena Bensoussan menggunakan hasil martingale yang ditemukan oleh Kunita-Watanabe. Dengan demikian, karena kerumitan yang timbul, aplikasi prinsip maksimum, paling tidak untuk masalah portofolio dan konsumsi optimum, tidak lebih baik dari teknik program dinamis stokastik.

Dalam tulisannya yang sangat menarik, Elliott (1990) berhasil mengatasi kerumitan penghitungan Bensoussan mengenai peubah adjoint dengan cara menggunakan sifat dapat diturunkannya (differentiability) persamaan diferensial stokastik. Penyederhanaan yang dilakukan Elliott terutama bergantung pada penyajian fungsi integran stokastiknya Bensoussan. Ternyata, penyajian peubah adjoint memenuhi persamaan diferensial parsial yang bersifat bukan stokastik.

Salah satu hasil penting yang ingin dikemukakan disini adalah bahwa terdapat hubungan antara prinsip maksimum dengan program dinamis. Terdapat dua cara dalam mempelajari masalah kontrol optimum stokastik : menggunakan prinsip maksimum yang dikembangkan oleh Pontryagin yang melibatkan proses adjoint $p$, dan dengan menggunakan program dinamis yang dikembangkan oleh Bellman 
yang melibatkan fungsi nilai $V$. (Definisi fungsi nilai $V$ dapat ditemukan dalam Fleming and Rishel (1975) dan Zhou (1990)). Secara umum, hubungan yang terdapat antara kedua pendekatan ini bersifat demikian rupa sehingga ada hubungan yang erat antara peubah adjoint $p$ dan fungsi nilai $V$. (Untuk detilnya dapat dilihat dalam Zhou (1990)). Elliott(1990) menyatakan bahwa hubungan tersebut demikian rupa sehingga $p_{x}=V_{x x}$.

\section{Daftar Pustaka}

[1] V.E. Benes, L.A. Shepp and Witsenhausen, 1980, Some Solvable Stochastic Control Problems, Stochastics, vol. 4, pp.39-83

[2] A. Bensoussan, 1982a, Lectures on Stochastic Control, Lecture notes in Mathematics, vol. 972 , pp.1-39

[3] A. Bensoussan, 1982b, Stochastic Control by Functional Analysis Methods, NorthHolland, Amsterdam

[4] A. Bensoussan, 1986, Current Results and Issues in Stochastic Control, Lecture Notes in Control and Information Sciences, vol. 78, pp. 36-88

[5] A Bensoussan, E.G. Hurst and B. Naslund, 1974, Management Applications of Modern Control Theory, North-Holland, Amsterdam

[6] A. Bensoussan, P. Kleindorfer and C. Tapiero, eds., 1980, Applied Stochastic Control in Econometrics and Management Science, North-Holland, Amsterdam

[7] R.J. Elliott, 1990, The Optimal Control of Diffusions, Applied Mathematcs and Optimization, vol. 22, pp. 229-240

[8] R.J. Elliott and M. Kohlmann, 1988, A Short Proof of Martingale Representation Result, Statistics \& Probability Letters, 6, pp. 327-329

[9] W.H. Fleming and R.W. Rishel, 1975, Deterministic and Stochastic Optimal Control, Springer-Verlag, New York

[10] U.G. Haussmann, 1981Some Examples of Optimal Stochastic Controls or : The Stochastic Maximum Principle at Work, SIAM Review, vol. 23, No. 3, July, pp. 292-307

[11] U.G. Haussmann, 1986, A Stochastic Maximum Principle for Optimal Control of Diffusions, Pitman Research Notes in Mathematics Series, vol. 151

[12] H.J Kushner, 1972, Necessary Conditions for Continuous Parameter Stochastic Optimization Problems, SIAM Journal Control, vol. 10, No. 3, August, pp. 550-564 
[13] R.C. Merton, 1971, Optimum Consumption and Portfolio Rules in a ContinuousTime Model, Journal of Economic Theory, No. 3, December, pp. 373-413

[14] B. Oksendal, 1985, Stochastic Differential Equations, Springer-Verlag, Berlin

[15] S. Peng, 1990, A General Stochastic Maximum Principle for Optimal Control Problems, SIAM Journal Control and Optimization, vol. 28, No. 4, July, pp. 966-979

[16] S.P. Sethi and G.L. Thompson, 1981, Optimal Control Theory : Applications to management Science, Martinus Nijhoff Publishing, Boston

[17] E. Syahril, 1991, A Maximum Principle in Stochastic Optimal Control, Graduate Diploma Project, Department of Applied Mathematics, The University of Adelaide, Adelaide

[18] X.Y. Zhou, 1990, The Connection Between the Maximum Principle and Dynamic Programming in Stochastic Control, Stochastics and Stochastics Reports, vol. 31, pp. $1-13$ 


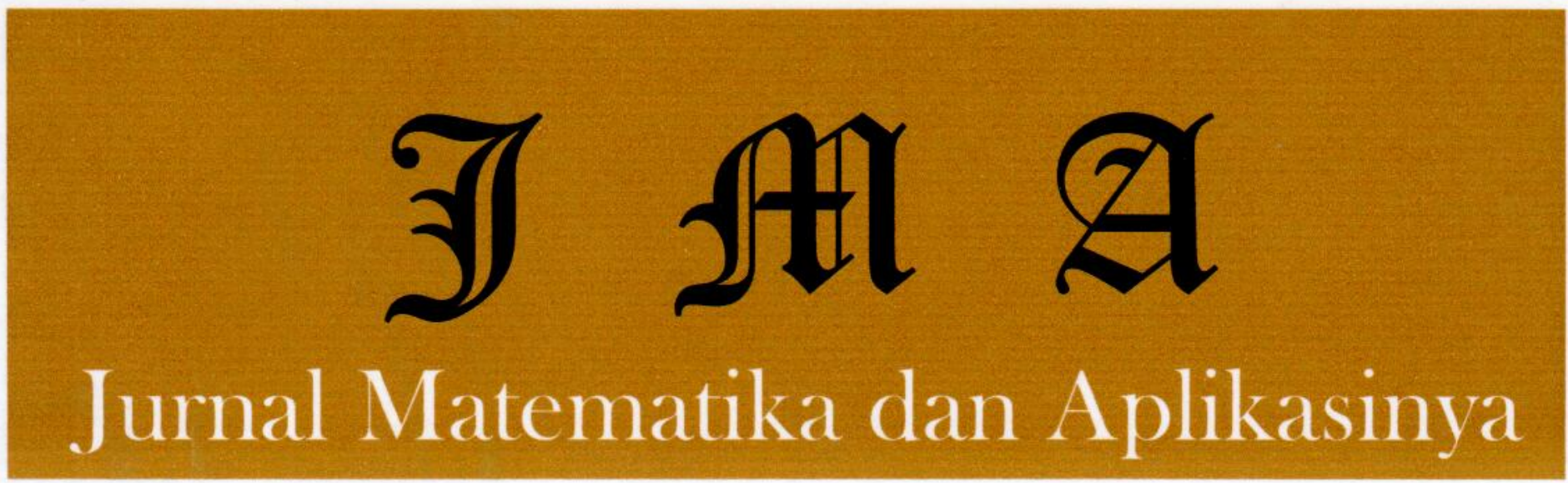

Volume 1, No. 2

Desember 2002

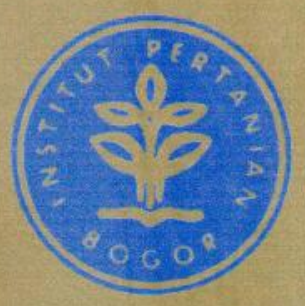

Alamat Redaksi :

Departemen Matematika FMIPA - Institut Pertanian Bogor Jin. Meranti Kampus IPB Dramaga Bogor

Phone/Fax:(0251) 625276

E-mail: math@ipb.ac.id

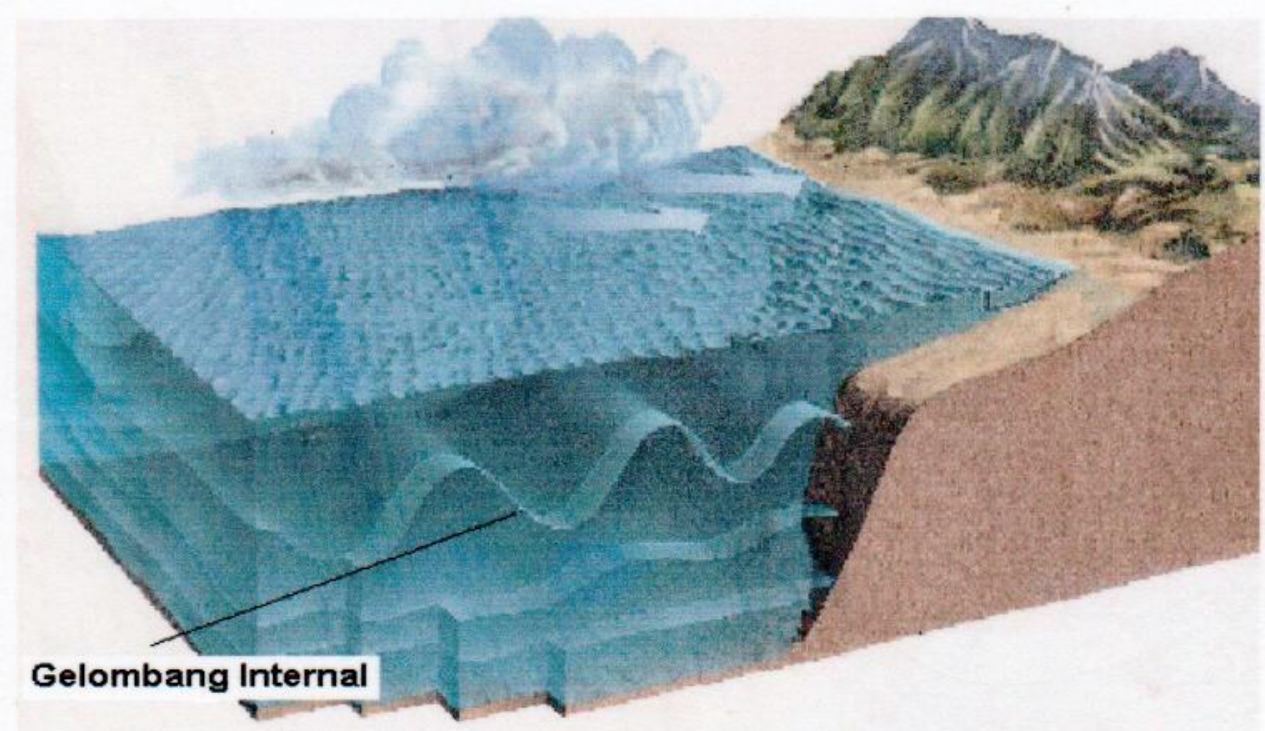

Essay on unified exposition of four major theorems in topology Agah D. Garnadi

A hidden Markov model: Dependencies between random variables and its representation

Berlian Setiawaty

Prinsip maksimum pontryagin dalam masalah kontrol optimum stokastik

Effendi Syahril

Discriminant functions and their misclassification errors

I Wayan Mangku

Suatu formulasi Lagrange bagi gerak gelombang internal Jaharuddin 


\section{Journal of Mathematics and Its Applications $\mathfrak{I} \mathfrak{A l A}$ \\ Jurnal Matematika dan Aplikasinya}

Essay on unified exposition of four major theorems in topology

Agah D. Garnadi

A hidden Markov model: Dependencies between random

variables and its representation

Berlian Setiawaty

Prinsip maksimum pontryagin dalam masalah kontrol

optimum stokastik

Effendi Syahril

Discriminant functions and their misclassification errors

I Wayan Mangku

Suatu formulasi Lagrange bagi gerak gelombang internal 